\title{
MANUFACTURING OF \\ FROZEN VEGETABLES
}

\author{
By
}

\section{Roshani Henadeera}

Thesis submitted in partial fulfillment of the

requirements for the degree of

\section{Master of Science}

In

Food Science and Technology

The faculty of Graduate studies

University of Sri Jayewardenepura

Sri Lanka

2006 


\section{DECLARATION}

The work described in this thesis was carried out by me under the supervision of Professor Arthur Bamunuarachchi and Dr. K.K.D.S. Ranaweera and a report on this thesis has not been submitted to any university for another degree and has not been presented or accepted in any previous application for a degree.

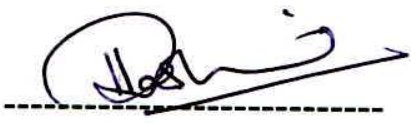

Roshani Henadeera 
We certify that the above statement made by the candidates is true and that this thesis is suitable for submission to the university for the purpose of evaluation.

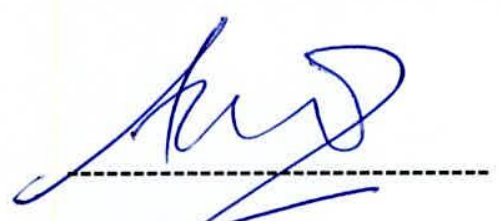

(Signature)

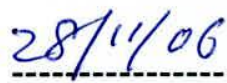

(Date)

Supervisor

Prof. Athur Bamunuarachchi

CO-ORDINATOR FOOD SCIENCE \&

TECHNOLOGY PROGRAMS,

DEPARTMENT OF FOOD SCIENCE \&

TECHNOLOGY,

UNIVERSITY OF SRI JAYEWARDENEPURA

SRI LANKA
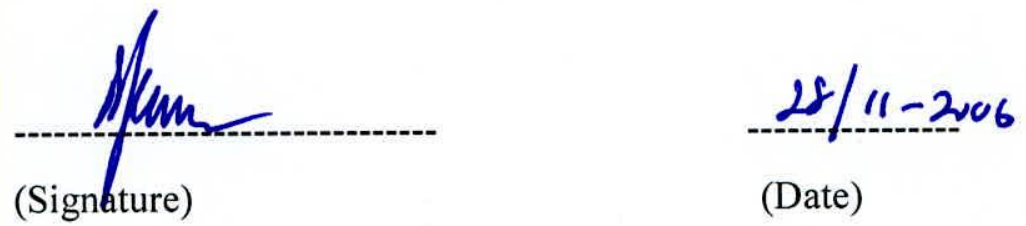

Supervisor

Dr. K.K.D.S. Ranaweera

HEAD,

DEPARTMENT OF FOOD SCIENCE \&

TECHNOLOGY,

UNIVERSITY OF SRI JAYEWARDENEPURA

SRI LANKA 
Affectionately dedicated

To

My loving Parents

And

Teachers 


\section{CONTENTS}

\section{PAGE}

Contents

i

List of tables

$\mathrm{V}$

List of figures vii

Abbreviations

viii

Acknowledgement

ix

Abstract

\section{Chapter 01}

Introduction

\section{Chapter 02}

Literature survey

2.1 Botany of Ipomoea aquatica (Kankun) and Alternanthera sessilis (Mugunuwenna)

2.1.1 General description

2.1.2 Botanical description

2.1.3 Nutritional properties

2.1.4 Utilization and benefits

$\begin{array}{lll}2.2 & \text { Selecting suitable material for freezing } & 6\end{array}$

2.3 Washing

2.4 Blanching

2.5 Packaging

2.6 Freezing

2.6.1 History of freezing

2.6.2 Freezing general view

2.6.2.1 Fundamental of freezing technology

2.6.2.2 Refrigerants

2.6.3 Distinction between refrigeration and freezing

2.6.4 What is freezing 
2.6.4.1.1 Contact with cold air/surface that is cooled by closed-loop recirculation freezing mechanism

2.6.4.1.1.1 Cold air systems

$\begin{array}{ll}\text { 2.6.4.1.1.2 Direct surface contact systems } & 15\end{array}$

$\begin{array}{lll}2.6 .4 .1 .2 & \text { Cryogenic systems } & 16\end{array}$

$\begin{array}{lll}\text { 2.6.4.1.3 Immersion freezing systems } & 16\end{array}$

$\begin{array}{lll}2.6 .5 & \text { Freezing methods } & 17\end{array}$

$\begin{array}{lll}2.6 .5 .1 \quad \text { Slow freezing } & 17\end{array}$

$\begin{array}{lll}2.6 .5 .2 & \text { Fast freezing } & 17\end{array}$

$\begin{array}{lll}\text { 2.6.6 Major changes happening at freezing } & 18\end{array}$

$\begin{array}{lll}2.6 .7 & \text { Effects of freezing and thawing } & 21\end{array}$

$\begin{array}{lll}2.6 .7 .1 & \text { Thawing } & 22\end{array}$

2.6.8 Effects of frozen storage 22

2.6.9 Other changes happening at freezing 24

$\begin{array}{lll}2.7 & \text { Quality evaluation } & 27\end{array}$

\section{Chapter 03}

Experimental

3.1 Determination of average weight of Ipomoea aquatica and Alternanthera sessilis bunches

3.2 Preliminary processing of Ipomoea aquatica and Alternanthera sessilis

3.2.1 Cleaning and washing 29

3.2.2 Determination of average weight of I. aquatica and A. sessilis $\begin{array}{ll}\text { bunch's edible portion } & 29\end{array}$

$\begin{array}{lll}3.2 .3 \text { Cutting } & 30\end{array}$

3.3 Determination of suitable blanching method for I. aquatica and $\begin{array}{ll}\text { A. sessilis } & 30\end{array}$

3.3.1 Determination of adequate time of hot water blanching 30

3.3.2 Determination of adequate time of steam blanching 31

3.3.3 Determination of losses during blanching 32

3.3.3.1 Determination of loss of vitamin $\mathrm{C}$ at blanching 32 
3.3.3.2 Determination of chlorophyll content losses at blanching

3.3.3.3 Determination of carotene content losses at blanching 35

3.4 Preparation of I. aquatica and A. sessilis for blanching 36

3.5 Weighing, Preparation of packets, Filling and Sealing 37

3.6 Freezing 38

3.7 Analytical studies on frozen I. aquatica and A. sessilis 39

3.7.1 Determination of the microbial quality of blast frozen I. aquatica and $A$. sessilis by total bacterial count (just after freezing) 39

3.7.2 Storage studies of frozen I. aquatica and A. sessilis 40

3.7.2.1 Determination of vitamin C content variation 40

3.7.2.2 Determination of chlorophyll content variation $\quad 41$

3.7.2.3 Determination of carotene content variation 41

3.7.2.4 Determination of drip loss during frozen storage $\left(-18^{\circ} \mathrm{C}\right)$

3.7.2.5 Determination of microbial quality variation during frozen storage $\quad 42$

3.7.2.6 Sensory evaluation 42

\section{Chapter 04}

Results and discussion

4.1 The determination of average weight of I. aquatica and

A. sessilis bunches

4.2 Preliminary processing of I. aquatica and A. sessilis

4.2.1 The determination of average weight of I. aquatica and A. sessilis bunch's edible portion

4.2.2 Cutting

4.3 Determination of suitable blanching method for

I. aquatica and A. sessilis

4.3.1 Determination of adequate hot water blanching time 47

4.3.2 Determination of adequate steam blanching time 47

4.3.3 Determination of losses during blanching 48

4.3.3.1 Determination of losses of vitamin $\mathrm{C}$ at blanching $\quad 48$

4.3.3.2 Determination of chlorophyll content loss at blanching $\quad 50$

4.3.3.3 Determination of carotene content loss at blanching 51 
4.4 Preparation of I. aquatica and A. sessilis for freezing 53

4.4.1 Blanching for freezing 53

4.4.2 Weighing 53

\begin{tabular}{ll|l}
4.4 .3 & Packaging & 53
\end{tabular}

\begin{tabular}{ll|l}
4.5 & Freezing & 53
\end{tabular}

4.6 Analytical studies on frozen I. aquatica and A. sessilis 54

4.6.1 Determination of the microbial quality of blast frozen I. aquatica and $A$. sessilis by total bacterial count (just after blast freezing) 54

$\begin{array}{ll}\text { 4.6.2 Storage studies of frozen I. aquatica and A. sessilis } & 54\end{array}$

\begin{tabular}{l|l} 
4.6.2.1 Determination of vitamin C content variation & 54
\end{tabular}

\begin{tabular}{l|l} 
4.6.2.2 Determination of chlorophyll content variation & 57
\end{tabular}

$\begin{array}{ll}\text { 4.6.2.3 Determination of carotene content variation } & 60\end{array}$

4.6.2.4Determination of drip loss during frozen storage $\left(-18^{\circ} \mathrm{C}\right) \quad 65$

4.6.2.5 Determination of microbial quality variation during frozen storage $\quad 69$

$\begin{array}{ll}\text { 4.6.2.6 Sensory evaluation } & 72\end{array}$

\section{Chapter 05}

$\begin{array}{lr}\text { Conclusion } & 80\end{array}$

$\begin{array}{ll}\text { References } & 82\end{array}$

\begin{tabular}{l|l} 
Appendix 01 & 85
\end{tabular}

\begin{tabular}{l|l} 
Appendix 02 & 86
\end{tabular}

\begin{tabular}{l|l} 
Appendix 03 & 87
\end{tabular}

Appendix $04 \quad 88$

Appendix 05

Appendix 06

Appendix 07

Appendix 08 


\section{LIST OF TABLES}

1 Nutritional values of Ipomoea aquatica 5

2 Nutritional values of Alternanthera sessilis 5

3 Average weight of a Alternanthera sessilis bunches 45

4 Average weight of a Ipomoea aquatica bunches 45

5 Average weight of the edible portion of Alternanthera sessilis bunch's

6 Average weight of the edible portion of Ipomoea aquatica bunch's

7 Time taken for hot water blanching of $A$. sessilis

8 Time taken for hot water blanching of I. aquatica 47

9 Time taken for steam blanching of $A$.sessilis 47

10 Time taken for steam blanching of I. aquatica 47

11 Standard curve data for vitamin C 48

12 Loss of vitamin $\mathrm{C}$ at blanching of $A$. sessilis 48

13 Loss of vitamin C at blanching of I. aquatica 50

14 Standard curve data for chlorophyll $\quad 50$

15 Loss of chlorophyll at blanching of $A$.sessilis 51

16 Loss of chlorophyll at blanching of I. aquatica 51

17 Loss of carotene at blanching of $A$.sessilis $\quad 51$

18 Loss of carotene at blanching of I. aquatica 53

19 Total bacteria count of the non-blanched samples (just after b.f.) 54

20 Total bacteria count of the steam-blanched samples (just after b.f.) $\quad 54$

21 Variation of vitamin C of blast frozen A sessilis 55

22 Variation of vitamin $\mathrm{C}$ of blast frozen I. aquatica 55

23 Variation of vitamin $\mathrm{C}$ of steam blanched slow frozen $A$.sessilis $\quad 56$

24 Variation of vitamin $\mathrm{C}$ of steam blanched slow frozen I. aquatica 56

25 Variation of chlorophyll content of blast frozen $A$.sessilis 57

26 Variation of chlorophyll content of blast frozen I. aquatica 57 
27 Variation of chlorophyll content of steam blanched slow frozen A .sessilis

28 Variation of chlorophyll content of steam blanched slow frozen 1. aquatica

29 Variation of carotene content of blast frozen A sessilis

30 Variation of carotene content of blast frozen I. aquatica

31 Variation of carotene of steam blanched slow frozen $A$. sessilis

32 Variation of carotene of steam blanched slow frozen I. aquatica

33 Drip loss analysis of $A$.sessilis

34 Drip loss analysis of $I$. aquatica

35 Variation of microbial quality during frozen storage (Result for the after two month sample)

36 Tabulated category scores for hedonic test for Mugunuwenna

37 Tabulated category scores for hedonic test for Kankun 


\section{LIST OF FIGURES}

1 Ipomoea aquatica plant with flower 85

2 Alternanthera sessilis plant $\quad 85$

3 Fruits of Alternanthera sessilis $\quad 86$

4 Ipomoea aquatica flowering plant and fruit $\quad 86$

5 Push through tunnel freezing systems $\quad 88$

6 Fluidization process of a fluidized-bed freezer 88

7 Typical horizontal plate freezer 89

8 Drum freezer drive mechanism $\quad 89$

9 Time-temperature data during freezing 19

10 Critical zone of temperature on freezing 20

11 Effects of freezing on plant tissues; (a) slow freezing (b) fast freezing 23

12 Effects of storage temperature on sensory characteristics 25

13 Structure of chlorophyll, carotene ( $\beta$-carotene) and other pigments 90

14 (a) The normal slow freezer used 91

(b) The blast freezer used (model BF 710) 91

15 Presenting the prepared A.sessilis as a Mallum for the sensory evaluation 75

16 Presenting the prepared I.aquatica as a Fried Kankun for the $\begin{array}{ll}\text { sensory evaluation } & 79\end{array}$

17 Standard curve data for vitamin C 49

18 Standard curve data for Chlorophyll 52

19 Variation of vitamin C during storage 59

20 Variation of Chlorophyll during storage 61

21 Variation of Carotene during storage 63

22 Drip loss \% v/w

(a) Alternanthera sessilis $\quad 66$

(b) Ipomoea aquatica $\quad 68$

23 The spectrophotometer used 92

24 Polythene sealer used 92

25 Prepared samples before blast freezing 93

26 Prepared samples to determining the cooling curve 93 


\section{LIST OF ABBREVIATIONS}

1. 2, 6-DCP =2, 6-Dichlorophenol-Indophenol

2. Internet. $=$ Taken from Internet Reference section

3. mth $=$ Months

4. $\operatorname{mins}=$ Minutes (time)

5. std $=$ Standard

6. S.B = Steam Blanched

7. N.B. = Non Blanched

8. H.W.B. = Hot Water Blanched

9. B.F./bf = Blast Frozen

10. S.F. $/ \mathrm{sf} \quad=$ Slow Frozen

11. $\mathrm{d}=$ Diameter

12. App1 = Appendix-01

13. App2 = Appendix -02

14. App3 $3=$ Appendix -03

15. App4 = Appendix-04

16. App5 $=$ Appendix -05

17. App6 = Appendix-06

18. App7 = Appendix-07

19. App8 = Appendix -08 


\section{Acknowledgement}

It is with pleasure that I express my affectionate and deeply felt gratitude to, advice, suggestion and given in numerous ways by my supervisors Prof. Athur Bamunuarachchi, Coordinator Food Science and Technology program, University of Sri Jayewardenepura and Dr. K.K.D.S. Ranaweera, Head of the Food Science and Technology Department, University of Sri Jayewardenepura.

I owe a deep debt of gratitude to Mr. Jagath Wansapala and Mrs. Indira Wicramasingha, Department of Food Science and Technology, University of Sri Jayewardenepura for the advice and support given me always.

I am greatly indebted to Mrs. Rupika Perera, Technical officer, Department of Food Science and Technology, University of Sri Jayewardenepura for given encouragement and guidance in numerous ways.

I offer my sincere appreciation and special thanks to Mr. Sisira Weerasinghe, Technical officer; Department of Food Science and Technology, University of Sri Jayewardenepura for give technical instruction and support to me during the tenure of my project.

I am grateful to Mr. Rupasingha, Laboratory Assistant; Department of Food Science and Technology University of Sri Jayewardenepura for supporting me always in my project work.

I wish to extend my thanks to Mr. Siripala Senadeera, Technical officer, Department of Chemistry, University of Sri Jayewardenepura for giving me chemicals and instruments throughout the project work.

I must acknowledge my debt to my friends for their support and encouragement given to me throughout the project work.

I offer my sincere appreciation and special thanks to my father who gave me assistance and constant encouragement to accomplish this project. 


\title{
Manufacturing of frozen vegetables
}

By

\author{
Roshani Henadeera, Prof. A. Bamunuarachchi, Dr.K.K.D.S. Ranaweera
}

\begin{abstract}
Leafy vegetables being rich in vitamins and minerals are one of the major constituents of our main meals. But due to their busy life, consumers cannot have access to fresh commodities and refrigerated vegetables may lose most of these nutrients and attributed sensory qualities.
\end{abstract}

A study was carried out to manufacture blast-frozen Kankun (Ipomoea aquatica) and Mugunuwenna (Alternanthera sessilis), which could retain nutrients, as do their fresh counterparts.

After blanching by using different heat treatment methods these vegetables were packaged by using LDPE appropriate for blast-freezing conditions. Subsequently, the food samples were subjected to blast-freezing as well as slow freezing. The temperature at the centre of the blast frozen samples reached $-28^{\circ} \mathrm{C}$. These frozen vegetables were stored and then analysed for vitamin $\mathrm{C}$, carotene, chlorophyll, pathogens and sensory properties including colour, flavour and texture periodically.

It was found that the duration of steam blanching adequate to inactivate peroxidase enzyme varies from species to other being $51 / 2$ minutes for Kankun and 1 minute for Mugunuwenna. As for hot water- blanching, these figures were 5 minutes and 30 second respectively.

However, among non-blanched, steam-blanched and hot water blanched vegetables, non-blanched samples were characterized by containing the highest contents of vitamin $\mathrm{C}$ and carotenes immediately after blast freezing. The reduction of these compounds in steam blanched has stopped while that of other samples continued longer. In addition, non-blanched blast-frozen samples were found to have less drip losses compared with steam blanched blast frozen; hot water blanched blast frozen and steam blanched slow frozen samples having the highest value. It may be possible to subject these vegetables to commercial scale blast- freezing. 


\section{CHAPTER-01}

\section{INTRODUCTION}

Competition and development have become the main targets in the modern world. As a result the world is busier than ever before. As a matter of fact consumer time and devotion for food preparation from buying to consumption are being deliberately reduced to utilize more time in working places and to create leisure time. Especially as more and more women are working out side their homes, this trend is very common in developed countries and fast spreading to the developing countries as well.

Compared to meat and fruits, vegetable preparation for meals has been more time consuming and troublesome. Because of this reason demand for convenient, minimally and fully processed vegetables has been in the ascend. Consumers are looking for more convenient ways for food preparation.

People being particular about taste, often prefer to cook their own food rather than buying cooked foods. Therefore minimally processed foods are often preferred to fully processed foods.

Research and development on freezing of vegetables is being done all over the world mainly for western vegetables. Very less work has been found on the indigenous types of vegetables in Sri Lanka. As such, representing Sri Lanka's leafy vegetables, the domestically common "Kankun (Ipomoea aquatica) and Mugunuwenna (Alternanthera sessilis) were examined for the possibility of manufacturing it as a frozen vegetable.

Blanching has been significant in vegetable freezing. Despite its beneficial effects, blanching can reduce the colour, flavour and texture of the vegetables. Determination of appropriate blanching time is crucial for all vegetables (Jayasekara, 2000). Among enzymes that could deteriorate vegetables, peroxidase is the most heat stable enzyme that cause off flavours, discolouration and textural damage (Jayasekara, 2000). Because of this reason, traditionally the blanching time determination is recommended to find the inactivation time of peroxidase enzyme for different blanching methods. Therefore 